\section{Marina Lostal, International Cultural Heritage law in Armed Conflict. Case studies of Syria, Libya, Mali, the Invasion of Iraq, and the Buddhas of Bamiyan, The Hague University of Applied Sciences, Cambridge University Press, 2017, 220 pages. ISBN 978-1-107-16921-0.}

Given the armed conflicts that have taken place in the MENA countries over the last decades, and the wealth of cultural heritage found in the area, this volume evaluates the legal situation of cultural property in conflictaffected states from the point of view of international law. That is why one of the main hypotheses is whether the protection of cultural heritage in the armed conflict is reoriented around the World Heritage Convention. The importance of this study is precisely the need to assess, and perhaps in some cases, to reconsider, certain international provisions so that the protection of the International Cultural Heritage Law in the conflict zones is respected. The volume is divided into six parts, structured in such a way as to understand the evolution of international cultural heritage protection. The author, starting with Part I, outlines the principles and schools of thought that have established the legal basis for international protection of cultural heritage. The volume is structured with an evolutionary and descriptive presentation of the main international conventions, declarations and norms that are the foundation of humanity's cultural security, so that in the last three parts an examination of the situations in the armed conflict areas is carried out.

Part I considers the need to re-evaluate international standards on the protection of cultural heritage, as the author considers should be contextually understood, so that other proposals and changes to be made. In order to question these international norms, the author examines the two great theories or schools of thought on the contouring of international law in the cultural dimension: revisionism and idealism. The first theory, revisionism, represents that theoretical approach in which the legal regime of cultural heritage is permanently affected and destroyed by various factors. The main idea that emerges from the enquiry is that revisionism is closely linked to the political and economic context. In this respect, normative acts from the 1907 Hague Conventions up to the 2003 UNESCO Declaration witnessed an evolution determined by the main armed conflicts and how they have brought changes due to destructions of cultural heritage. On the other hand, idealism is the promoter for developments through international courts to assess rights, obligations and sanctions in relation to cultural heritage. Idealism considers that the legislation must not be always readjusted, as it has reached a maturity that allows only a simple regulation through international institutions. Idealists believe that cultural heritage law has a human dimension, being an erga omnes obligation to respect it, and implicitly the entire humanity. What the author appreciates is that both revisionism and idealism, support the need for a proper legal framework.

The second part is dedicated to the characteristics of the International

\section{Paul Popa}

Babeș-Bolyai University Cluj Napoca paul.p.popa@gmail.com

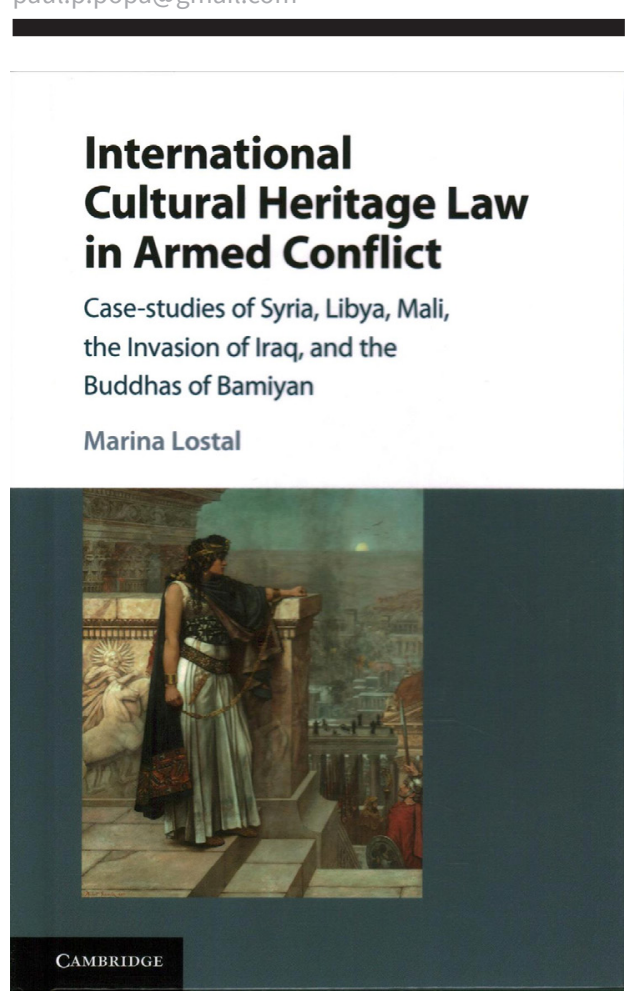

DOI: $10.14795 /$ j.v6i2.405

ISSN $2360-266 \mathrm{X}$

ISSN-L 2360 - 266X 
Cultural Heritage Law, considered "essentially adversal", which expresses "cultural internationalism" and which assumes that cultural property belongs to humanity, not just to a state. To illustrate different international regulations, the author presents the main principles underlying them. The principle of prevention (to eliminate all threats to cultural objectives), the principle of relative interest (which states that international law on cultural heritage is in the common interest of all). In this context, the author makes a distinction between cultural property and cultural heritage, underlining that "all cultural property is part of cultural heritage". It also mentions the principle of differentiated duties on the legal consequences of the responsibility to ensure the protection of cultural heritage (between states, the international community, local communities, etc.). A distinction is made between the abovementioned principles and the principles applied in the armed conflict. Thus, the principle of prevention is resumed, plus the principle of Third-and Fourth-Order Distinction, which implies a gradual differentiation between the categories of those involved in the armed conflict: combatants, non- combatants, military or civilian objectives, but also differences between civilian property and cultural objects, or between cultural property and cultural heritage. Another principle is the relative proportionality: collateral cultural damage, which reflects those cultural objectives that are destroyed as a result of attacks on military objectives, so that military attacks are adapted to the position of the cultural objectives or cultural heritage in order to protect them.

The third part explores the World Heritage Convention as the common legal denominator, since it has the highest degree of universality among all international normative acts on cultural heritage protection. Following the presentation of its evolution and features, the author deliberates some critics about how binding it is, but also the role it enjoys in relation to the armed conflict, but also the effects it has. Thus, the author scrutinizes, from the point of view of the Vienna Convention, its universal and binding applicability to all international actors, which ultimately emphasizes its importance.

Part 4 is devoted to the comparative analysis between the 1954 World Heritage Convention and the 1954 Hague Convention, which, although they have an integrative approach, have failed to bring everyone a unanimous support. The author outlines the situation of Syria, both in terms of armed conflict and cultural property. This presents the monuments destroyed by the terrorist groups, the armed forces, but also the response and the measures adopted by the relevant organizations: UNESCO, ICOMOS, ICOM, UNSC, etc. It also presents the preventive measures adopted based on Article 3 of the 1954 Hague Convention and its limitations, in the sense that there are certain situations in which it cannot be stated which are the specific cultural property to which they apply. Also, maps and inventories should often be used, and according to art. 7 of the 1956 Hague Convention, there may be an inclusion of cultural property in wartime manuals and instructions. After the outbreak of hostilities, state protection measures can be taken, which is obliged to take the necessary actions to maintain the integrity of the cultural property, taking into account the differences between "measures" and "deliberate", the latter being more specific. Even if all measures to prevent and protect cultural property are found in both treaties, their existence ensures a more complex and broad interpretation and investigation of what violation of international law means.

Parts 5 and 6 show how the conflicts in Mali and Libya, namely Afghanistan and Iraq, destroyed sites, but also procedures taken by states and international organizations. The study is well documented and describes the losses and the political actions that led to their damages. The conclusions are related to the fact that the international norms, in this case the 1954 Hague Convention and the World Heritage Convention along with the 1999 Second Protocol, create a great complexity, which should be coordinated to best sanction the violations of cultural law. It should also be borne in mind that these measures and regulations must be reported and correlated with other international provisions, but also with the customary law.

The book describes best the applicability of international provisions on the protection of cultural heritage and cultural property by analyzing the mechanisms and instruments needed to prevent and protect the world cultural heritage. It also presents the deviations from the international provisions that took place in the conflicts in certain areas. In this respect, the author considers that the terrorist activity carried out by groups such as ISIS is not only a violation of cultural heritage, but as serious violations of international law. The author, through her arguments, appeals to the solidarity of the international community, precisely because these combats cause further damage to the cultural heritage of humanity. Thus, it is our duty to let everyone inherit our identity as a civilization, as our descendants should understand the evolution that mankind has gone through. 